\section{Вступне слово головного редактора}

Ось і добігає свого кінця 2020 рік, рік незвичайних і надзвичайних викликів, який ніби випробовував нас на стійкість, на витримку, на мудрість, на виживання врешті. Ми проходили чи не найскладніший в своєму житті тест - тест на гуманність, на гідність, на здатність допомогти слабшому, захистити потерпаючого, підставити плече втомленому. Ковід-19 всім сплутав карти. Але загалом українське суспільство вистояло, хоч і $з$ втратами, продемонструвало свою опірність негараздам. Але перед загальнонаціональними і навіть глобальними небезпеками так і не об'єдналося. Це наочно продемонстрували Національні круглі столи, які проводилися по всій Україні впродовж осені 2020. Ні в питаннях культури чи істоpiї, мови чи релігії українці не є єдиними. Вони досі поділені на тих, хто 3А, і тих, хто ПРОТИ - стратегії розвитку країни, шляхів вирішення важливих суспільних проблем. Не стало менш проблемним і релігійне життя в країні, яке вимушено було зменшити свою інтенсивність, переглянути масштабність і регулярність присутності в соціумі і в житті кожної людини. Багато розгорнутих в минулі роки і успішно діючих проєктів прийшлося згорнути. Така вже звична активність церков - i релігійна, i соціальна - зазнала змін. Тепер вона існує в нових формах. Але це не зменшило гостроти проблем в сфері релігійної свободи i свободи совісті, не прибрало 3 порядку денного необхідності провадити міжрелігійний діалог чи налагоджувати партнерські відносини з державою. Деяку плутанину в цю сферу внесла реорганізація державного органу влади, який відповідає за державно-церковні відносини: попередній Департамент у справах релігій та національностей МКУ ліквідовано, а новий Державна служба з етнополітики та свободи совісті тільки розгортає свою діяльність.

Все це розширило предметне поле для дослідження ситуації, що складається. Науковці, незалежні експерти як з України, так і закордоння оперативно реагували на виклики ковідної епохи.

Цей номер журналу відкривається традищійним вже екскурсом в історію постання і розвитку ідеї релігійної свободи. Відомий український дослідник М.Бабій подав нову статтю, вже третю, присвячену генезі ідеї свободи релігійної совісті в добу Середньовіччя, боротьбі різноманітних підходів, які представлені мислителями західно- і східнохристиянської традиції. Враховуючи намір автора продовжити знайомити читачів i надалі з розгортанням людського розуміння та обгрунтування свободи совісті, свободи віросповідання, наш журнал в цій частині є своєрідним текстом лекцій для прочитання спецкурсу студентам університетів.

Ми продовжуємо обговорення документу ОБСС «Свобода релігії або переконань та безпека. Керівництво з питань політики (2019)», який друкували в попередніх журналах (https://uars.info/prints/rs/2223/10.pdf; https://uars.info/ index.php/rs/article/view/1822/1830) і до якого вже долучилися міжнародні експерти в попередніх числах журналу, зокрема С. Феррарі (https://uars.info/index.php/rs/article/view /2096/1831).

На цей раз висловив свою думку запрошений відомий вітчизняний експерт зі свободи релігії професор В.Сленський. Його стаття «Між релігійною свободою і національною безпекою. Документ ОБСС 
«Свобода релігії або переконань та безпека» в західному, російському та українському контекстах» розтлумачує особливості співвідношення питання релігійної свободи і національної безпеки. Фактично твориться нова західна безпекова політика, яка несе ризики релігійній свободі і правам людей в цій сфері. Автор, аналізуючи підхід до узгодження питань релігійної свободи і національної безпеки в Російській Федерації, вважає, що «обмеження релігійної свободи, які мотивуються інтересами національної безпеки, є такими, що знищують основоположні міжнародні принципи у сфері свободи совісті й переконань і ставлять Росію в один ряд 3 найбільш брутальними порушниками релігійних свобод у світі». В.Сленський фахово доводить, що Україна, навіть в умовах колосальних зовнішніх i внутрішніх викликів, може зберегти баланс між релігійною свободою i безпекою, демонструючи свою відданість європейським цінностям демократії.

Автори наступного матеріалу «Православна церква і державна ідеологія в сучасних українських реаліях» якраз і прагнуть віднайти отой баланс. Порівнюючи російську та українську модель державно-церковних відносин, В.Попович та В.Таран критично підходять до прикладів ігнорування 3 боку церков історичних реалій, сучасних тенденцій розвитку релігійного світу. Вони загалом висновують, що «взаємозв'язок Церкви та державної ідеології є цілком закономірним явищем», про що свідчить досвід багатьох країн світу, де релігія виступає одним із важливих факторів формування державної ідеології. Зупиняючись на аналізі ситуації в православ'ї, зокрема українському, вони визнають наявність відмінностей між різними його частинами, які, на їхню думку, «стосуються не стільки суто церковно-релігійних проблем, скільки проблем політико-ідеологічних». Суперечність між прихильниками проукраїнських та проросійських світоглядноціннісних орієнтацій автори пропонують вирішувати шляхом осучаснення самого православ'я, формування його відкритості, через удосконалення політики у сфері відносин між державою і церквою, посилювати позиції української держави, що впливатиме на ефективність міжконфесійного діалогу, на стан релігійної свободи в Україні.

Про ненадумані переслідування за віру, які прагне нав'язати українському суспільству УПЦ МП, пише Юлія Філь. Досліджуючи в своїй статті «Міжнародне товариство свідомості Кришни (ISKCON) в період війни на Донбасі (2014 - 2019)» ті виклики - і практичні, і світоглядні, з якими стикається ця організація, авторка висновує, що, грунтуючись на своїх віросповідних принципах, «вайшнавська громада жодним чином не втручається у справи війни і не приймає жодну із сторін», але в практичні площині старається задовільнити базові потреби не тільки своїх адептів, але й всіх, хто потребує допомоги. Разом 3 тим, «індивідуальна позиція кожного відданого могла збігатися з позицією ISKCON, а могла відрізнятися від неї залежно від особистого досвіду вайшнава», що забезпечило певну стабільність в житті МТСК: без розколів, без припинення діяльності, збереження дружнього спілкування між різними спільнотами.

Стаття відомої російської релігієзнавищі К.Елбакян «Релігійне різноманіття як фактор суспільної безпеки» (англ.м.) суттєво доповнює наші знання про різноманітність релігійного життя в Росії, зокрема про ситуацію зі свідками Єгови. На прикладі цієї 
релігійної спільноти професорка доводить, що переслідування за релігійною ознакою не зміцнює безпеку країни, a, навпаки, «створює ряд досить серйозних ризиків для стабільного функціонування соціуму як «всередині» держави, так і на міжнародній арені». Висновок очевидний: безпековість країни напряму залежить від стану релігійної свободи, рівня цивілізованості державно-релігійних відносин.

Абсолютно протилежною до російської $є$ ситуація зі свідками Сгови в Україні, про що ми дізнаємося зі статті К.Бережка та Ю.Кіреєва «Свідки Єгови в сучасному світі та Україні». Стаття давно вже лежала в редакції, ніби чекала актуалізації теми подіями в Росії та реакції світової наукової громадськості. Пропонований матеріал цікавий тим, що тут можна знайти статистичні дані щодо кількості членів конфесії, які відсутні в офіційних державних джерелах, цікаві архівні документи 3 історії руху, спогади самих віруючих про спробу держреєстрації у 1949 році. Політика комуністичного режиму щодо свідків зробила їх дещо закритими для суспільства, породивши багато міфів, які продукувалися самим тоталітарним устроєм. Грунтуючись на доброму знанні фактів, автори розповідають про нинішню діяльність організації, про зміну у ставленні віруючих до українського суспільства.

Редакція слідкує за новинами в науковому житті, тому не могла не відреагувати на декілька знакових подій цього року. Однією з них стала конференція «Свідки Єгови та їхні опоненти: Росія, Захід і не тільки», яка була зініційована професором Массімо Інтровін'є і проведена його Центром дослідження нових релігій (CESNUR) у вересні 2020. Нарешті поважне наукове середовище світу так потужно відреагувало на сучасні переслідування свідків Єгови в Росії. Журнал пропонує огляд цієї події, українську версію короткого змісту виступів основних доповідачів, які можна прослухати в повній версії в запису (https://freedomofbelief.net/activities/jehovahs-witnesses-and-their-opponents-russia-the-west-andbeyond), а текст почитати в журналі (The Journal of CESNUR, volume 4, issue 6, November-December 2020. https://cesnur.net/. Переклад з англійської на наше прохання здійснив Центр Свідків Єгови в Україні).

Проблема зі свідками Єгови вписується в загальний, так званий антисектантський дискурс, який періодично виникає як в українських, так і міжнародних реаліях. Часто це пов' язано із появою нової течії або активізацією вже існуючих неорелігій, коли суспільство вимагає відповіді від експертів щодо цих явищ - наскільки вони безпечні для тієї чи іншої країни. Але частіше всього наявне незнання, відсутність достовірної інформації супроводжується агресією і не виправданими правовими ініціативами, як це сталося влітку 2020 в Україні.

Реагуючи на цей антисектантський сплекс, редакція журналу друкує звернення, з яким оперативно виступила Українська асоціація релігієзнавців, надрукувавши його на своїй сторінщі (https:/ / ureonline.info/zakon-pro-sekty-ukrayinskaasocziacziya-religiyeznavcziv-reaguye-na-proyekt-zakonu/), і який переклала англомовна агенція Europeantimes для ознайомлення світової громадськості із можливими небезпеками обмеження релігійних свобод в Україні в разі прийняття антисектантських ініціатив частини депутатів Парламенту України (https://www.europeantimes.info/2020/08/03/attempted-discriminating-law- 
on-religions-in-ukraine/?fbclid=IwAR2c8LY1yFVJFDkPrCWwH-3RleuKS3qoxsK9eDqjTD3Ra9kuOHoAcWNTazU).

Як завжди в таких випадках, ми звертаємося за авторитетною думкою всесвітньо знаних експертів. Нам відповіла британська дослідниця, засновниця міжнародного інформаційно-дослідницького центру в Лондоні INFORM доктор соціології Айлін Баркер, статтю якої англійською мовою ми публікуємо на сторінках цього номеру журналу. Професорка вкотре наголошує, що у своєму ставленні до нових релігій суспільство навіть демократичні країни не завжди справедливі та об'єктивні. Так, автори і підписанти Загальної декларації прав людини чи Європейської конвенції 3 прав людини, заявляючи про свою підтримку прав віруючих людей та релігійних організацій, вдаються до дискримінацій релігій, особливо НРТ. Це робиться не так прямо, відкрито і грубо як в країнах, де обмежується релігійний плюралізм, більш приховано і тонко, але це - все одно, серйозні обмеження свободи віросповідання і свободи діяльності релігійних організацій.

Наприкінці журналу ми анонсуємо декілька видань, які з'явилися в сфері плюральності релігійного життя та захисту релігійної свободи, та подаємо список авторів, які своєю інтелектуальною працею збагатили наш науковий досвід.

Вітаючи всіх із завершенням 2020 i настанням 2021, який мав би бути до нас більш поблажливим, від імені редакції і себе особисто хочу подякувати всім тим, хто зробив 25 номер «Релігійної свободи». Це і автори, які завжди вражають нас оригінальністю і фундаментальністю своїх тем i розмірковувань, це і рецензенти, які уважно читають подані статті, часто не тільки їх рецензуючи, але й редагуючи, чим покращують подані тексти, які ми через відсутність в штаті професійних редакторів вимушені друкувати в авторській редакції. Але особлива подяка невидимим працівникам редакції, завдяки яким журнал набуває свого очікуваного вигляду: мій вчений секретар, права рука, головний порадник - доктор філософських наук Віта Титаренко; адміністратор журналу, від пильного ока якого не заховається найдрібніша неточність в оформленні статті та процедурі іï подання на сайт - Георгій Филипович; редакторка англомовної частини журналу Юлія Розумна; авторка обкладинки і беззмінна макетувальниця журналу, яка доводить той весь набір статей та інформацій до світового рівня журнальної продукції - Леся Скубко. Будьмо здорові, i фізично, і духовно, щоб мати сили продовжувати велику справу утвердження релігійної свободи в світі та Україні.

3 любов'ю і доброю пам'яттю про внесок всіх і кожного,

\section{Людмила Филипович}

